\title{
Effect of yeast culture on milk production and metabolic and reproductive performance of early lactation dairy cows Piret Kalmus*†1, Toomas Orro ${ }^{2}$, Andres Waldmann ${ }^{3}$, Raivo Lindjärv ${ }^{4}$ and Kalle Kask ${ }^{1}$
}

Address: ${ }^{1}$ Department of Therapy, Institute of Veterinary Medicine and Animal Science, Estonian University of Life Sciences, Tartu, 51014, Estonia, ${ }^{2}$ Department of Environment and Animal Health, Institute of Veterinary Medicine nad Animal Science, Estonian University of Life Sciences, Tartu, 51014, Estonia, ${ }^{3}$ Department of Reproductive Biology, Institute of Veterinary Medicine and Animal Science, Estonian University of Life Sciences, Tartu 51014, Estonia and ${ }^{4}$ Department of Infectious Diseases, Institute of Veterinary Medicine and Animal Science, Estonian University of Life Sciences, Tartu, 51014, Estonia

Email: Piret Kalmus* - piret.kalmus@emu.ee; Toomas Orro - toomas.orro@emu.ee; Andres Waldmann - waldmann@ut.ee; Raivo Lindjärv - raivo.lindjarv@emu.ee; Kalle Kask - kalle.kask@emu.ee

* Corresponding author †Equal contributors

Published: 3 August 2009

Acta Veterinaria Scandinavica 2009, 51:32 doi:10.1186/175I-0147-5I-32

Received: 24 October 2008

Accepted: 3 August 2009

This article is available from: http://www.actavetscand.com/content/5I/1/32

(c) 2009 Kalmus et al; licensee BioMed Central Ltd.

This is an Open Access article distributed under the terms of the Creative Commons Attribution License (http://creativecommons.org/licenses/by/2.0), which permits unrestricted use, distribution, and reproduction in any medium, provided the original work is properly cited.

\begin{abstract}
Background: The main objective of this study was to estimate the effect of supplementation with Saccaromyces cerevisiae (SC) (Yea-Sacc ${ }^{\circledR}$ 1026) on milk production, metabolic parameters and the resumption of ovarian activity in early lactation dairy cows.

Methods: The experiment was conducted during 2005/2006 in a commercial tied-house farm with an average of 200 milking Estonian Holstein Friesian cows. The late pregnant multiparous cows (n $=46$ ) were randomly divided into two groups; one group received $10 \mathrm{~g}$ yeast culture from two weeks before to 14 weeks after calving. The groups were fed a total mixed ration with silages and concentrates. Milk recording data and blood samples for plasma metabolites were taken. Resumption of luteal activity was determined using milk progesterone $\left(\mathrm{P}_{4}\right)$ measurements. Uterine bacteriology and ovarian ultrasonography (US) were performed and body condition scores (BCS) and clinical disease occurrences were recorded. For analysis, the statistical software Stata 9.2 and $\mathrm{R}$ were used to compute Cox proportional hazard and linear mixed models.
\end{abstract}

Results: The average milk production per cow did not differ between the groups (32.7 \pm 6.4 vs $30.7 \pm 5.3 \mathrm{~kg} /$ day in the $\mathrm{SC}$ and control groups respectively), but the production of milk fat $(P<$ $0.00 \mathrm{I})$ and milk protein $(P<0.00 \mathrm{I})$ were higher in the SC group. There was no effect of treatment on BCS. The analysis of energy-related metabolites in early lactation showed no significant differences between the groups. In both groups higher levels of $\beta$-hydroxybutyrate (BHB) appeared from days 14 to 28 after parturition and the concentration of non-esterfied fatty acid (NEFA) was higher from days I-7 post partum (PP). According to US and $\mathrm{P}_{4}$ results, all cows in both groups ovulated during the experimental period. The resumption of ovarian activity (first ovulations) and time required for elimination of bacteria from the uterus did not differ between the groups.

Conclusion: Supplementation with SC had an effect on milk protein and fat production, but did not influence the milk yield. No effects on PP metabolic status, bacterial elimination from the uterus nor the resumption of ovarian activity were found. 


\section{Background}

Metabolic health is the successful adaptation of the dairy cow for higher energy requirements and metabolic changes during early lactation $[1,2]$. Many strategies, such as direct supplementation of propylene glycol, undegradable starch and monensin, have resulted in a positive effect on glucose production, but feeding dietary fat or specific fatty acids have not demonstrated improved energy status [3-6].

Based on a growing concern over the use of antibiotics and other growth promoters in the animal feed industry, interest in the effects of microbial feed additives on animal performance has increased. Supplementation with yeast culture has been used for over six decades and milk production responses have been investigated by several researchers. In some studies, cultures have improved dry matter intake, milk yield, and milk composition [7-11] whilst other studies have found no significant impact [1216]. The energy balance of dairy cows is itself a key regulator of reproductive performance, changing the overall metabolic status during the periparturient period, which can lead to a delay in the resumption of ovarian activity and uterine involution. It has been established recently that the prolongation of postpartum NEB is a factor associated with low reproductive performance in dairy cows [17-19]. Many studies have demonstrated that the magnitude of NEB is related to the interval to first ovulation $[17,20]$. Animals suffering from NEB will have reduced resistance, which can lead to uterine infections and affect the PP uterus cleansing [21].

The objective of the study was to observe if cows with better fibre digestion and higher production values, may also show improved concentrations of energy related metabolites such as BHB and NEFA. If this is so, those animals might have a better energy balance, which may positively influence uterus cleaning and earlier resumption of ovarian activity. Considering previously described studies, microbial feed additives could be those substances which can help dairy cows better adapt to lactation needs and improve reproductive performance.

\section{Methods \\ Cows and feeding}

The experiment was carried out between December 2005 and May 2006 on a commercial tied-house farm with an average of 200 milking Holstein Friesian cows. The 46 late pregnant multiparous cows were randomly divided into two groups before calving, and were housed in separate rows on the farm. All cows calved during a two month period. Ten grams of SC (Yea-Sacc ${ }^{\circledast} 1026$, Alltech Biotechnology Center, Nicolasville, YK, USA) were hand-mixed with a small amount of concentrate and were fed daily to each cow from the experimental group before morning feeding, starting from two weeks before the expected calving date until 14 weeks after parturition. Ten grams of SC is the recommended dosage according to Yea-Sacc ${ }^{\circledast} 1026$ instructions. The cows were fed the same total mixed ration (TMR) diet. The TMR consisted of a grass silage and concentrate mix. Four different silage batches were used during the experimental period (Table 1). To control for the effect of different silage batches on the treatment, the feeding times of the silage batches were included in the statistical models.

\section{Milk production data and body condition score}

During the first 90 days in milk (DIM), cow identification number, date of calving, daily milk yield and disease occurrence data were recorded. Cows were milked twice a day. Every second day daily milk yield of cows was measured by automatic milking system (Milkmaster, Delaval). The milking units were checked before commencing recording according to DeLaval instructions.

Milk production data, including kg of milk produced, percentage and $\mathrm{kg}$ of milk fat and milk protein were recorded by the Estonian Animal Recording Centre every second week until 14 weeks after parturition. Body condition scores (BCS) were recorded once per week from the day of calving until week thirteen PP by trained personnel using a 5 -point scale $(1=$ thin and $5=$ fat $)$ as described by Edmondson [22].

\section{Collection of milk samples for progesterone analysis}

Milk collection for progesterone $\left(\mathrm{P}_{4}\right)$ analysis was collected twice a week (Monday and Thursday) starting from the second week PP until the thirteenth week. In order to avoid the effect of the time of milk extraction on the $\mathrm{P}_{4}$

Table I: Chemical composition of the silages fed during the study period.

\begin{tabular}{lllll}
\hline Parameter & Silage I & Silage 2 & Silage 3 & Silage 4 \\
\hline Feeding period * & I. & 2. & 3. & 4. \\
\hline Dry matter \% & 40.3 & 32.7 & 39 & 32.7 \\
\hline Crude protein\% of DM & 15.86 & 13.65 & 14.8 & 16.12 \\
\hline NDF \% of DM & 40.9 & 58,2 & 58 & 46.03 \\
\hline ADF \% of DM & 35.1 & 34.8 & 36.1 & 31.7 \\
\hline ME MJ/kg of DM & 9.47 & 9.65 & 9.84 & 10.18 \\
\hline
\end{tabular}

* Feeding period of different silages

Silage I: 15.12.05-05.01.06

Silage 2: $06.01 .06-11.02 .06$

Silage 3: 12.02.06-27.03.06

Silage 4: $28.03 .06-20.05 .06$ 
concentration, samples were collected not later than $1 \mathrm{~h}$ after the morning milking [23]. Milk (10 - $15 \mathrm{ml})$ was collected by handstripping into plastic tubes containing potassium dichromate as a preservative. Samples were frozen at $-18^{\circ} \mathrm{C}$ until $\mathrm{P}_{4}$ analysis. Before analysis, milk samples were left to stand at room temperature overnight to thaw. The following day samples were centrifuged and concentrations of $\mathrm{P}_{4}$ in the milk were measured by enzyme immunoassay (EIA) according to Waldmann [24]. The inter- and intra-assay coefficients of variation were $<10 \%$. The limit of sensitivity using a $20 \mu$ l sample was $0.5 \mathrm{ng} / \mathrm{ml}$. Resumption of luteal activity was defined as the first two consecutive measurements of $\mathrm{P}_{4}$ concentrations > $3 \mathrm{ng} / \mathrm{ml}$. Prolonged anoestrus was determined when consistently low $\mathrm{P}_{4}$ concentrations were measured for at least 50 days. [25]

\section{Plasma metabolites}

Coccygeal blood vessel samples for biochemical analysis were collected in heparinized Venoject glass tubes (Terumo Europe N. V., Leuven, Belgium) once per week during the first 92 days PP.

After immediate centrifugation $(15 \mathrm{~min}$ at $1048 \times \mathrm{g})$, approximately $5 \mathrm{ml}$ of plasma was removed and stored at $-20^{\circ} \mathrm{C}$ until analysis. An automatic multiparameter analyser for clinical chemistry (EOS Bravo; Hospitex Diagnostics s.r.l., Italy) was used for enzymatic determination of plasma $\beta$-hydroxybutyrate (BHB) and non-esterified fatty acids (NEFA) with a commercially available kits (Randox Laboratories Ltd, UK).

\section{Collection of uterine biopsy specimen for bacteriological examination}

Each animal in the study was sampled bacteriologically using endometrial biopsies once per week, starting within 7 days PP. Biopsy specimen collection was terminated when at least two consecutive negative samples were reported. In animals that only had negative samples from the beginning of collection, sampling was terminated after 3 weeks PP. Endometrial samples were collected aseptically according to the techniques and methods described previously by Kask et al.[26]. Biopsy specimens were immediately placed in a thioglycolate medium for transport to the Unit of Veterinary Microbiology, Estonian University of Life Sciences, for bacteriological examination. Cultivations were made within $1.5 \mathrm{~h}$ after collection. Standard bacteriological procedures according to Bergey's Manual of Systematic Bacteriology [27] were employed.

\section{Ultrasonographic examination of ovaries}

The ultrasound (US) equipment was a real time B-mode linear array scanner (Hondex HS-120, Honda Electronics Co., Ltd., Aichi, Japan), with a 7.5 MHz transducer. Prints from a videographic printer were obtained. Ultrasound recording commenced 10 days PP and was performed twice per week (Tuesday and Friday) until the start of regular ovarian activity. Follicular activity was monitored in the ovaries. The sizes of the largest follicle and corpus lutea (CL) were monitored and measured by freezing the images and using callipers. Based on the size measurements, follicular dynamics were estimated. Ovulation was judged to have occurred if the dominant largest follicle(s) monitored by US could not be detected at the next examination, corpus luteum development was seen during subsequent examinations, and this was confirmed by a subsequent increase in $\mathrm{P}_{4}$ concentration [26]. All structures in the ovaries of more than $2.5 \mathrm{~cm}$ in diameter, and persisted for more than 10 days, were considered to be cysts [28].

\section{Statistical analysis}

Health data were analyzed by the Fisher Exact Test using the statistical software Stata 9.2 [29]. Polynomial linear random-intercept models were used to explore time trend differences in milk production data, metabolic parameters and BCS between the experimental and control groups. Cows were included as random intercepts and polynomials of time in increasing order from parturition in days (or in weeks for milk fat and protein models) and their interactions with treatment were added as fixed effects until significant. Overall time trend differences between groups were tested with the F-test. The silage ratio was controlled in every model, and cow lactation time was included if significant. In the milk fat and protein models, milk yield on the sample day was used as a significant covariate. As the time between sampling was not the same in all cows, an isotropic spatial exponential correlation structure was used for modelling serial correlations of repeated measurements at the within-cow level in models for the metabolic parameters. In models for BCS, milk constitutes and milk yield, a first-order autoregressive (AR1) correlation structure was used as the time between sample points remained constant. The model assumptions were verified by scatter and normality plots of standardized residuals and logarithmic transformation of BHB, NEFA, BCS, and milk fat kg were used. The NLME package [30] with statistical software R 2.5.0 [31] was used for fitting these polynomial linear random-intercept models.

The Cox proportional hazards model was used to explore group differences in the timing of first rise in milk progesterone concentration (in weeks from parturition) and the time when uterine bacteriological examinations were reported to be negative (in weeks from parturition). The statistical software Stata 9.2 [29] was used for these models. 


\section{Results}

\section{Clinical diseases and exclusions}

Altogether seven animals were removed from the experiment during the study period. Left displaced abomasum $(\mathrm{n}=3)$, rumen collapse $(\mathrm{n}=1)$ and downer cow syndrome $(n=2)$ were diagnosed in the control group. One case of downer cow syndrome was diagnosed in the experimental group. Final group sizes were 22 in the experimental group and 17 in the control group.

\section{Milk production}

Supplementation with SC had no statistically significant effect on milk production over the study period. Mean $( \pm$ SEM) daily milk yield was $32.7 \pm 1.39 \mathrm{~kg} / \mathrm{d}$ for the experimental group and $30.7 \pm 5.3 \mathrm{~kg} / \mathrm{d}$ for the control group. The changes in milk yield over time are illustrated in Figure 1. From 40 days PP, the milk yield in the two groups was similar and the curves did not differ significantly $(P=$ 0.12 ). Both milk fat and protein production over time were significantly lower in the control group $(P<0.001$ and $P<0.001$, respectively; Figure 2 ). There was no effect of treatment on changes of BCS over time. A decrease in BCS was seen after parturition and the lowest scores were detected between days 56 and 63 PP in both groups (Figure 3 ). Figure 4 presents the changes in BHB and NEFA during the period up to 91 days PP.

Analyses of energy-related metabolites during early lactation showed no significant differences between the groups. An increase in BHB appeared from days $14-28$
PP in both groups, where the decrease in NEFA stabilized on day $21 \mathrm{PP}$.

\section{Uterine bacteriology}

In total, 234 uterine biopsies were collected from 39 cows, where $62(26.5 \%)$ were found to have positive bacteriology results and the remaining 172 (73.5\%) were negative. At the beginning of lactation, biopsies from 12 cows proved to be without bacterial growth. Of the 62 bacteriologically positive samples, 12 (19.3\%) showed mixed infections and $50(80.7 \%)$ had one of either aerobic or anaerobic cultures. The most frequently isolated anaerobic bacterium was Fusobacterium necrophorum (25\%) whereas Streptococcus spp (30\%) and Arcanobacterium pyogenes $(22 \%)$ were the principal aerobic bacteria. The mean bacterial elimination time from the uterus was the third week in experimental group and the fourth week in the control group. No difference was found between the groups.

\section{Ovarian ultrasonography and $\mathbf{P}_{\mathbf{4}}$}

According to ovarian US, follicular activity was detected in all cows in both groups in the first US session on day 10 $\mathrm{PP}$. The US and $\mathrm{P}_{4}$ results indicated that all cows in both groups ovulated during the experimental period. Prolonged anoestrus was detected in six cows (27\%) in the experimental group and seven cows (41\%) in the control group. Knowing that ovulation occurs approximately five days before this progesterone rise [25], the median (range) of resumption of luteal activity (first ovulations) was day 37 (14-93) in the experimental group and day 35

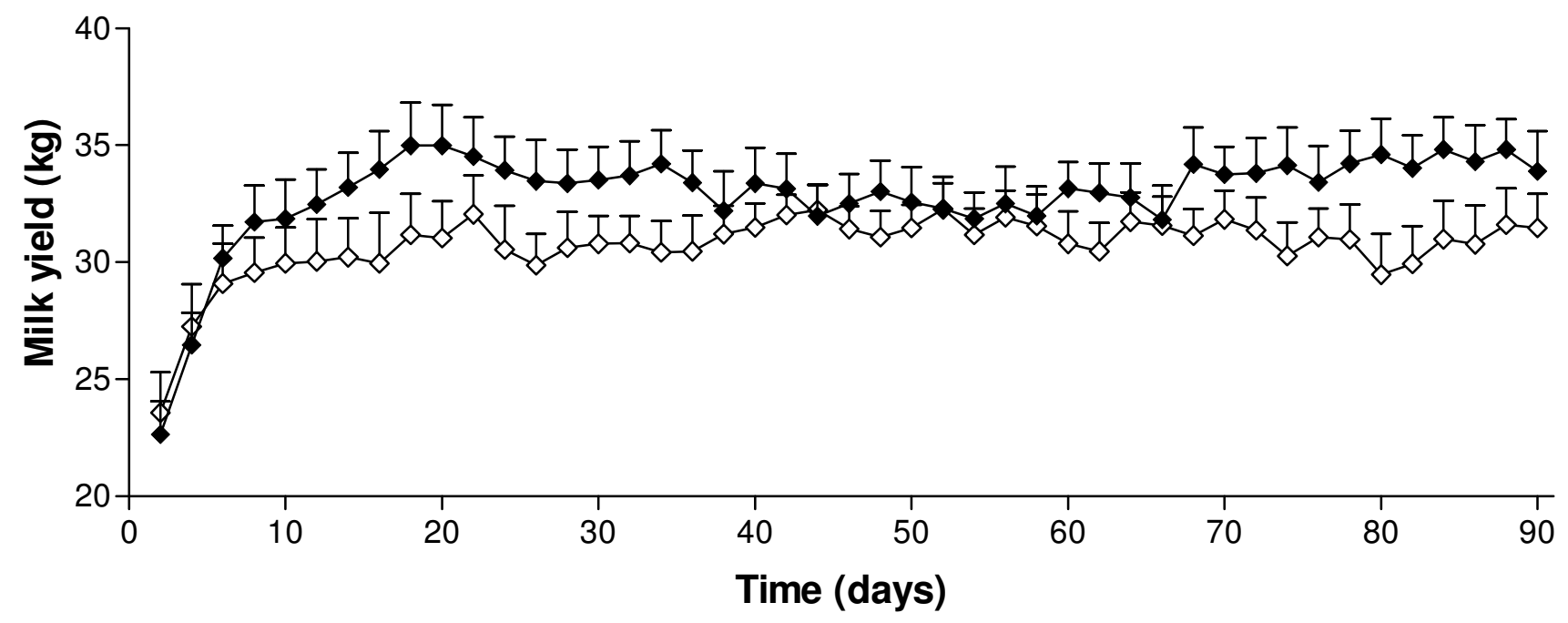

Figure I

Mean daily milk yield in Saccaromyces cerevisiae and control group. Mean $( \pm$ SEM) daily milk yield during the first 90 days from parturition (measured every second day) in cows from the Saccaromyces cerevisiae group (black diamond; $\mathrm{n}=22$ ) and control group (white diamond; $n=17$ ). 

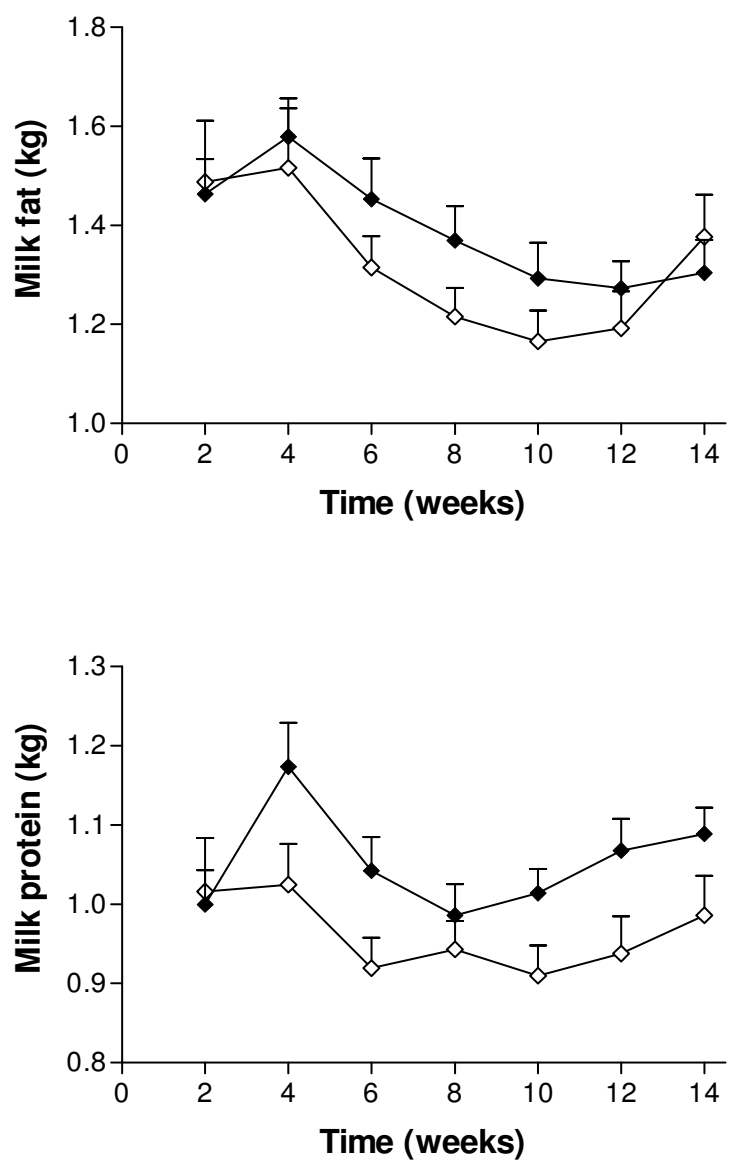

Figure 2

Mean daily milk fat and protein production in Saccaromyces cerevisiae and control group. Mean ( \pm SEM) daily milk fat (above) and milk protein (below) during the first 14 weeks from parturition (measured every second week) in cows from the Saccaromyces cerevisiae group $(\bullet ; n=22)$ and control group $(\vee ; n=17)$.

(9-112) in the control group. Before the onset of ovulation, regular ovarian activity (follicular waves with dominant follicle appearance and regression) was detected in both groups. The occurrence of ovarian cysts during the first four weeks PP was detected in five (22.7\%) animals in the experimental group and four (23.5\%) animals in the control group. There were no statistical differences between the groups.

\section{Discussion}

\section{Milk yield and composition}

Although not statistically significant, this equates to cows receiving SC having numerically higher (5.8\%) milk yield than the controls. However, the sample size in the current study was very small to achieve significance for such numerical increases. Many studies have also reported an increase in milk yield, but again the effects have not been

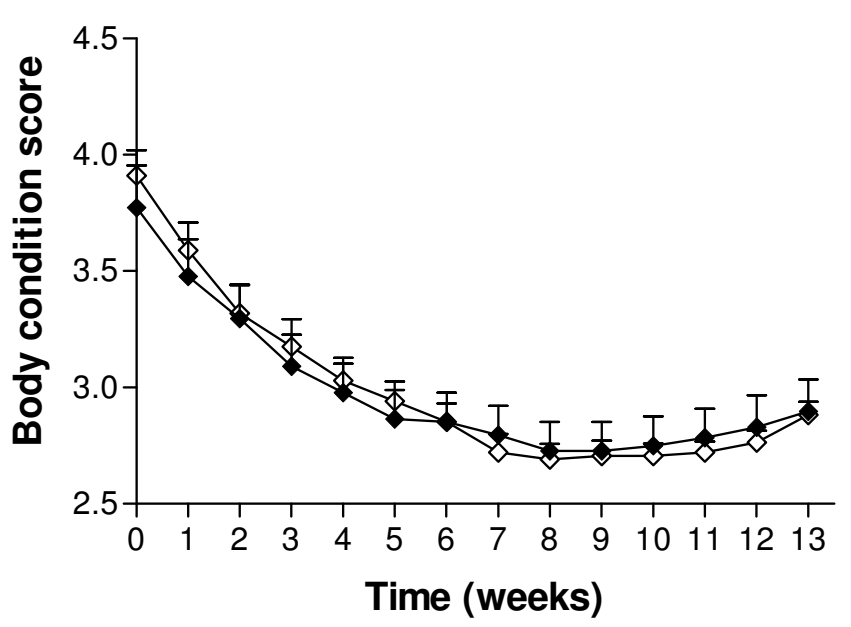

Figure 3

Mean body condition score in Saccaromyces cerevisiae and control group. Mean $( \pm$ SEM) body condition score during the first I 3 weeks from parturition (measured weekly) in cows from the Saccaromyces cerevisiae group (black diamond; $\mathrm{n}=22$ ) and control group (white diamond; $\mathrm{n}$ $=$ I7).

significant [32-36]. Some trials have noted a response to yeast supplementation only in early lactation cows $[7,9,36]$. Our study also showed that the largest difference between the groups appeared during the first six weeks PP.

Nocek et al. [37,38] reported increased milk fat and protein percentages when direct-fed microbial product was supplemented. We also found an impact of yeast supplementation on the milk protein and fat components, especially during early lactation. An explanation for the higher milk protein content in the experimental group could be the well-known impact of yeast on rumen fermentation and nutrient digestibility which enhances ammonia uptake and improves microbial protein production $[8,39,40]$. Increased milk fat percentage in very early lactation is often associated with adverse events such as excessive negative energy balance, rapid mobilization of body fats, and subclinical ketosis. However, neither mean blood $\mathrm{BHB}$ concentration nor the proportion of cows with elevated $\mathrm{BHB}$ concentrations increased in the experimental group. Similarly an effective digestion of fiber, in the form of neutral detergent fibre (NDF), will increase the number of cellulolytic bacteria in the rumen [41] and this could also influence milk fat content. For example, yeast supplementation had a significant effect on milk fat and protein content when NDF in the ration was $21 \%$ compared with $17 \%$ [42]. However, a lack of response in milk fat in many studies $[8,12,13,15]$ could be indicative that the stimulation of fibre-digesting ruminal bacteria was sufficient for milk fat synthesis in those experiments. 

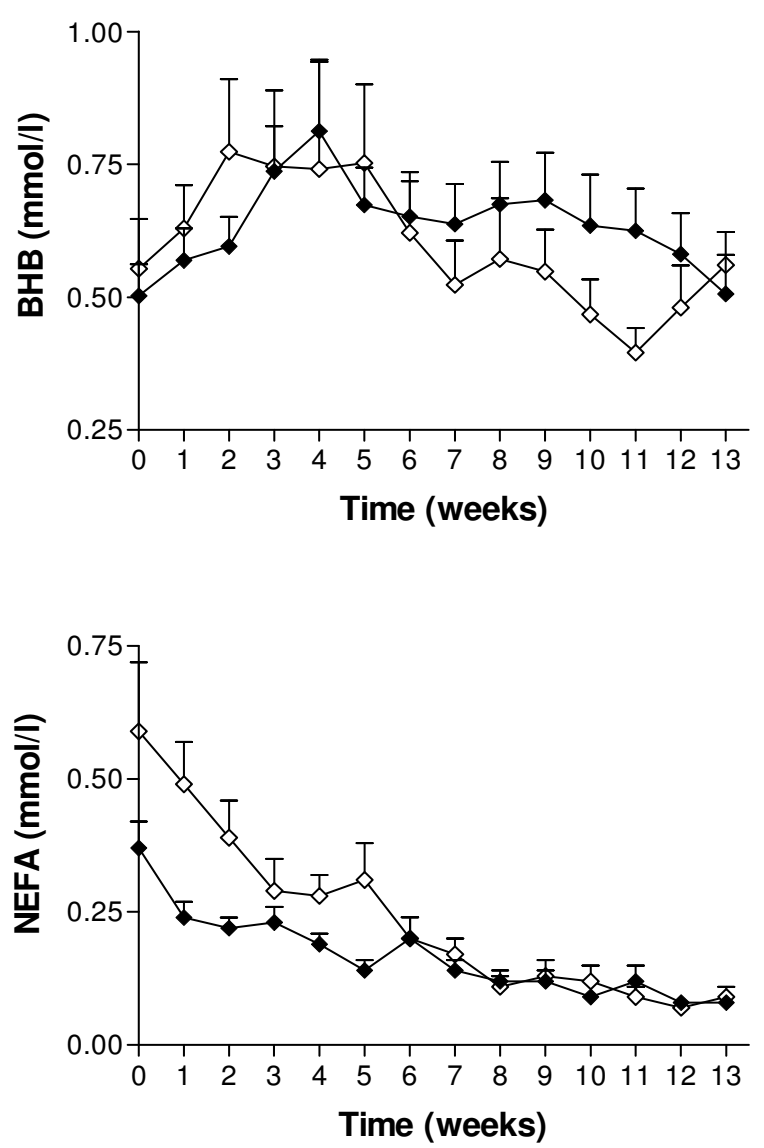

Figure 4

Mean daily $\beta$-hydroxybutyrate and non-esterified fatty acid concentrations in the Saccaromyces cerevisiae and in the control group. Mean ( \pm SEM) daily $\beta$ hydroxybutyrate $(\mathrm{BHB})$ concentrations (above) and nonesterified fatty acid (NEFA) concentrations (below) during the first I 3 weeks from parturition (data pooled by sample week) in cows from the Saccaromyces cerevisiae group ( $\bullet$; $=22)$ and control group $(\diamond ; n=17)$.

\section{Metabolic parameters}

Several factors including BCS, NEFA, the fat/protein ratio in milk, and ketone bodies have been found to be suitable parameters for indirect detection of energy balance. $[21,43,44]$. Milk from cows in the experimental group consisted of more protein and fat, which could indicate that stable rumen health may improve energy consumption PP and prevent serious metabolic changes. Elevated BHB levels suggest that fatty acids are being oxidized and that cows may be in a more severe state of negative energy balance [45], but no differences were found in our study. We found a higher concentration of NEFA around the time of calving in both groups, but subsequently stabilisation in concentrations was seen in the third week PP. The same findings have been described by other studies $[37,38,46]$

\section{Reproductive performance}

Negative energy balance may affect ovarian activity by decreasing LH pulsativity, which leads delayed resumption of luteal activity [47]. Uterine infections have also been reported as risk factors for delayed ovulation [48]. To rule out endometritis as a possible cause for delayed ovulation, bacterial elimination time was investigated.

In our study, both groups showed a similar resumption of ovarian activity. Previous studies where direct-fed microbials $[46,49]$ were used, also had no effect on reproductive function.

However, a large field study with a greater number of cows and herds is needed to determine the influence of yeast culture supplementation on reproductive performance.

\section{Conclusion}

Based on the results of this investigation, supplementation with SC had an effect on milk protein and fat production, but did not influence the milk yield. No effect on PP metabolic status, bacterial elimination from uterus nor the resumption of ovarian activity were found.

\section{Competing interests}

The authors declare that they have no competing interests.

\section{Authors' contributions}

PK carried out the study, compiled the results and drafted the manuscript. TO participated in designing the study and statistical analysis of the data. AW participated in data collection and coordinated laboratory analysis, RL performed bacteriological analysis and KK coordinated the study. All authors were significantly involved in designing the study, interpreting data and composing the manuscript.

\section{Acknowledgements}

The Estonian Science Foundation is acknowledged for financial support (grant No 5733, 6065 and 7891) and Alltech Biotechnology Center, Nicolasville, YK, USA (Trial Number 05-E-1434) for supplying the yeast culture product used in the trial.

\section{References}

I. Goff JP, Horst RL: Physiological Changes at Parturition and Their Relationship to Metabolic Disorders I,2. J Dairy Sci I997, 80:1260-1268.

2. Overton TR, Waldron MR: Nutritional Management of Transition Dairy Cows: Strategies to Optimize Metabolic Health. J Dairy Sci 2004, 87:E I05-EI I9.

3. Phipps RH, Wilkinson JID, Jonker LJ, Tarrant M, Jones AK, Hodge A: Effect of monensin on milk production of Holstein-Friesian dairy cows. J Dairy Sci 2000, 83:2789-2794.

4. Stokes SR, Goff JP: Evaluation of calcium propionate and propylenglycol administered into the oesophagus at calving. Prod Anim Sci 200I, 17:1 I5-122. 
5. Pickett MM, Piepenbrink MS, Overton TR: Effects of propylenglycol or fat drench on plasma metabolites, liver composition, and production of dairy cows during the periparturient period. J Dairy Sci 2003, 86:2|I3-2|2I.

6. Juchem SO, Santos FAP, Imaizumi H, Pires AV, Barnabé EC: Production and blood parameters of Holstein cows treated prepartum with sodium monensin or propylene glycol. J Dairy Sci 2004, 87:680-689.

7. Wohlt JE, Finkelstein $A D$, Chung $\mathrm{CH}$ : Yeast culture to improve intake, nutrient digestibility, and perfomance by cattle during early lactation. J Dairy Sci 1991, 74:1395.

8. Erasmus LJ, Botha BM, Kistner A: The effects of yeast culture supplement on production, rumen fermentation and duodenal nitrogen flow in dairy cows. J Dairy Sci 1992, 75:3056.

9. Robinson PH, Garret JE: Effect of yeast culture (Saccaromyces cerevisiae) on adaptation of cows to postpartum diets and on lactatational perfomance. J Animal Sci 1999, 77:988-999.

10. Huber JT, Sullivan J, Taylor B, Burgos A, Cramer S: Effect of feeding Yea-Sacc on milk production and related responses in a commercial dairy herd in Arizona. In Biotechnology in the Feed Industry Volume 5. Alltech Technical Publications, Nicholasville, KY; 1989.

11. Williams PE, Tait CA, Innes GM, Newbold C): Effects of the inclusion of yeast culture (Saccharomyces cerevisiae plus growth medium) in the diet of dairy cows on milk yield and forage degradation and fermentation patterns in the rumen of steers. J Animal Sci 1991, 69:3016-26.

12. Swartz DL, Muller LD, Rogers GW, Varga GA: Effects of yeast cultures on performance of lactating dairy cows: A field study. J Dairy Sci 1994, 77:3073-3080.

13. Soder KJ, Holden LA: Dry matter intake and milk yield and composition of cows fed yeast prepartum and postpartum. J Dairy Sci 1999, 82:605-610.

14. Schingoethe DJ, Linke KN, Kalscheur KF, Hippen AR, Rennich DR, Yoon I: Feed efficiency of mid-lactation dairy cows fed yeast culture during summer. J Dairy Sci 2004, 87:4178-4I8I.

15. Arambel MJ, Kent BA: Effect of yeast culture on nutrient digestibility and milk yield response in early- to mid-lactation dairy cows. J Dairy Sci 1990, 73:1560-1563.

16. Henics Z, Combos S: Effects of yeast culture on milk production, feed digestibility and ruminal fermentaion of dairy cattle. In Biotechnology in the Feed Industr Volume 8. Alltech Technical Publication, Nicholasville, KY; 1992.

17. Beam SW, Butler WR: Energy balance and ovarian follicle development prior to the first ovulation postpartum in dairy cows receiving three levels of dietary fat. Biology of Reproduction 1997, 56:133-142.

18. Staples CR, Burke JM, Thatcher WW: Influence of supplemental fats on reproductive tissues and performance of lactating cows. J Dairy Sci 1998, 8 I:856-87I.

19. Butler ST, Pelton SH, Butler WR: Energy balance, metabolic status, and the first postpartum ovarian follicle wave in cows administered propylene glycol. J Dairy Sci 2006, 89:2938-295I.

20. Zurek E, Foxcroft GR, Knenelly JJ: Metabolic status and interval to first ovulation in postpartum dairy cows. J Dairy Sci 1995, 78:1909-1920.

21. Suriyasathaporn W, Nielen M, Dieleman SJ, Brand A, NoordhuizenStassen EN, Schukken YH: A cox proportional hazard model with time dependent covariates to evaluate the relationship between body condition score and the risks of first insemination and pregnancy in a high-producing dairy herd. American Journal of Preventive Medicine 1998, 37:159-172.

22. Edmondson AJ, Lean IJ, Weaver LD, Farver T, Webster G: A body condition scoring chart of Holstein dairy cows. J Dairy Sci I989, 72:68-78.

23. Waldmann A, Ropstad E, Landsverk K, Sørensen K, Sølverød L, Dahl $\mathrm{E}$ : Level and distribution of progesterone in bovine milk in relation to storage in the mammary gland. Animal Reproduction Science 1999, 56:79-91.

24. Waldmann A: Monoclonal antibodies to progesterone: characterization and selection for enzyme immunoassay in bovine milk. Hybridoma 1999, 18(3):289-296.

25. Opsomer G, Coryn M, Deluyker H, de Kruif A: An Analysis of Ovarian Dysfunction in High Yielding Dairy Cows After Calving Based on Progesterone Profiles. Reprod Dom Anim 1998, 33:193-204.
26. Kask K, Kurykin J, Lindjärv R, Kask A, Kindahl H: Assessment of early postpartum reproductive perfomance in two high producing Estonian dairy herds. Acta Vet Scan 2003, 44: 131 I- 134.

27. Holt JG, Krieg NR, Sneath PH, Statley JT, Williams ST: Bergys's manual of Determinative Bacteriology 9th edition. Williams and Wilkins Co, Baltimore; 1994.

28. Roberts SJ: Veterinary Obstetrics and Genital Diseases. In Theriogenology 3rd edition. Edwards Brothers, Inc. Ann Arbor, Michigan; 1986.

29. Stata 9.2. 2005 Stata® Statacorp LP, College Station, USA.

30. Pinheiro J, Bates D, Debroy, Sarhar D: Linear and nonlinear mixed effect models. $R$ package version 3.I-73 2006.

31. R-soft. R Development Core Team R: A language and environment for statistical computing. R Foundation for Statistical Computing, Vienna, Austria; 2006.

32. Erdman RA, Sharma BK: Effect of yeast culture and sodium bicarbonate on milk yield and composition in dairy cows. J Dairy Sci 1989, 72: 1929.

33. Bernard JK: Influence of supplemental yeast on the performance of Holstein cows during early lactation. J Dairy Sci 1992, 75(SuppI I):3I2.

34. Kung L, Kreck EM Jr, Tung RS, Hession AO, Sheperd AC, Cohen MA, Swain HE, Leedle JAZ: Effects of a live yeast culture and enzymes on in vitro ruminal fermentation and milk production of dairy cows. J Dairy Sci 1997, 80:2045-205I.

35. Robinson PH: Effect of yeast culture (Saccharomyces cerevisiae) on adaptation of cows to diets postpartum. J Dairy Sci 1997, 80: III9-II25.

36. Dann HM, Prockley JR, McCoy GC, Hutjens MF, Garret JE: Effects of yeast cultures (Saccharomyces cerevisiae) on prepartum intake and postpartum intake and milk production of Jersey cows. J Dairy Sci 2000, 83:123-I27.

37. Nocek JE, Kautz WP, Leedle JA, Block E: Direct-fed microbial supplementation on the performance of dairy cattle during the transition period. J Dairy Sci 2003, 86:33I-335.

38. Nocek JE, Kautz WP: Direct-fed microbial supplementation on ruminal digestion, health, and performance of pre-and postpartum dairy cattle. J Dairy Sci 2006, 89:260-266.

39. Harris B Jr, Webb DW: The effect of feeding a concentrated yeast culture product to lactating dairy cows. J Dairy Sci 1990, 73(SuppI I):266.

40. Miller-Webster T, Hoover WH, Holt M: Influence of yeast culture on ruminal microbial metabolism in continuous culture. J Dairy Sci 2002, 85:2009-2014.

41. Dawson KA, Newman KE, Boling JA: Effects of microbial supplements containing yeast and lactobacilli on roughage-fed ruminal microbial activities. J Animal Sci 1990, 60:3392.

42. Wang Z, Eastridge ML, Qiu X: Effects of forage neutral detergent fiber and yeast culture on performance of cows during early lactation. J Dairy Sci 200 I, 84:204-2I2.

43. Rukkwamsuk T, Wensing T, Geelen MJ: Effect of overfeeding during the dry period on regulation of adipose tissue metabolism in dairy cows during the periparturient period. J Dairy Sci 1998, 8 I:2904-29II.

44. Le Blanc S: Monitoring programs for transition dairy cows. proceedings of the World Buiatric Congress, Nice, France; 2006:460-47I.

45. Lean IJ, Farver TB, Trout ML, Bruss JC, Galland R, Baldwin L, Holmberg CA, Weaver LD: Time series cross-correlation analysis of postparturient relationships among serum metabolites and yield variables in Holstein cows. J Dairy Sci 1992, 75: I89I- 1898.

46. Francisco CC, Chamberlain CS, Waldner DN, Wettemann RP, Spicer LJ: Propionibacteria fed to dairy cows. Effects on energy balance, plasma metabolites and hormones, and reproduction. J Dairy Sci 2002, 85: 1738-175I.

47. Opsomer G, Gröhn YT, Hertl J, Coryn M, Deluyker H, de Kruif A: Risk factors for post partum ovarian dysfunction in high producing dairy cows in Belgium: a field study. Theriogenology 2000, 53:84I-857.

48. Mateus L, da Costa LL, Bernardo F, Silva JR: Influence of puerperal uterine infection on uterine involution and postpartum ovarian activity in dairy cows. Reprod Domest Anim 2002, 37:31-35.

49. Stein DR, Allen DT, Perry EB, Bruner JC, Gates KW, Rehberger TG, Mertz K, Jones D, Spicer LJ: Effects of Feeding Propionibacteria to Dairy Cows on Milk Yield, Milk Components, and Reproduction. J Dairy Sci 2006, 89: II I-I25. 